\title{
Effect of Intracoronary Glycoprotein IIb/IIIa Inhibitor and Manual Aspiration Thrombectomy on Primary Percutaneous Coronary Intervention Outcome in High Thrombus Burden Patients Mohammed Hussam Al-Din Al-Shaer, Yasser Gaber Ibrahim Metwally, Mohammed Abdelhady Mohammed, Alsalhen Fathi A. Ibsaekri* Department of Cardiology, Faculty of Medicine, Zagazig University, Egypt \\ *Corresponding author: Alsalhen Fathi A. Ibsaekri, Mobile: (+20) 01061948143, E-mail: mohf76174@gmail.com
}

\begin{abstract}
Background: The opening of a related artery in myocardial infarction as quickly as possible is the key to treating infarct. Percutaneous coronary intervention (PCI) for recanalization of related infarcted arteries is considered the most effective therapy for myocardial infarction.

Objective: To estimate the intracoronary delivery of glycoprotein IIb/IIIa following manual thrombus aspiration on outcomes post PCI for patients with high thrombus burden.

Patients and Methods: This was a randomized control trial that was conducted on 48 patients presented to Zagazig University Hospital Emergency Cardiac Unit with ST elevation myocardial infarction for primary percutaneous coronary intervention, the need for reperfusion therapy was assessed according the European Society of Cardiology (ESC) Guidelines for the management of acute myocardial infarction in patients presenting with ST-segment elevation. Patients were randomized into three groups: (1) Manual aspiration group (16 patients). (2) Manual aspiration with intracoronary glycoprotein IIb/IIIa group (19 patients), and (3) Intracoronary glycoprotein IIb/IIIa group (13 patients).

Results: There was significant difference between manual aspiration group, manual aspiration with intracoronary glycoprotein IIb/IIIa group and intracoronary glycoprotein IIb/IIIa group as regard the outcomes in high thrombus burden patients.
\end{abstract}

Conclusion: Combination glycoprotein IIb/IIIa and manual aspiration is better then single modality for high thrombus burden patients.

Keywords: Intracoronary Glycoprotein, Manual Aspiration, Percutaneous Coronary Intervention, Thrombectomy.

\section{INTRODUCTION}

The opening of a related artery in myocardial infarction as quickly as possible is the key to treating infarct ${ }^{(1)}$. Percutaneous coronary intervention (PCI) for recanalization of related infarcted arteries is considered the most effective therapy for myocardial infarction ${ }^{(2)}$.

Myocardial recovery after the primary percutaneous coronary intervention (PCI) is often suboptimal despite restoration of thrombolysis in myocardial infarction (TIMI) 3 flow, in part due to thrombus remobilization, which results in impaired microvascular perfusion and increased infarct size ${ }^{(\mathbf{3})}$.

Aspiration thrombectomy and intracoronary platelet glycoprotein (GP) IIb/IIIa receptor antagonists are widely used to reduce distal embolization ${ }^{(4,5)}$. GP $\mathrm{IIb} / \mathrm{III}$ receptor antagonists can reduce thrombus burden and secondary distal embolization microcirculation ${ }^{(6)}$.

Measuring infarct size after reperfusion therapy offers important prognostic utility. Laboratory measures of infarct size include biomarkers such as creatinine phosphokinase, lactate dehydrogenase, and troponin levels. While these tests are promptly available and can be obtained in the acute setting, they are unreliable in comparison to infarct size assessed by cardiac imaging ${ }^{(7)}$.
Some studies suggest that the intracoronary application of platelet membrane GP IIb/IIIa receptor antagonists improves myocardial perfusion; however,

such studies are currently few, and their results are controversial (8,9). Most of these studies used abciximab as their GP IIb/IIIa receptor antagonist, and tirofiban was rarely used ${ }^{(\mathbf{1 0})}$.

This study aimed to selection of best method for treatment of patients with high thrombus burden.

\section{PATIENTS AND METHODS}

A randomized control trial that was conducted on 48 patients presented to Zagazig University Hospital Emergency Cardiac Unit with ST elevation myocardial infarction for primary percutaneous coronary intervention, the need for reperfusion therapy was assessed according the ESC Guidelines for the management of acute myocardial infarction in patients presenting with ST-segment elevation ${ }^{(\mathbf{1 1})}$.

\section{Ethical consideration:}

This study was submitted for approval by the Institution Research Board (IRB) of Zagazig University Institution. Informed consent was obtained from each participant sharing the study. Confidentiality and personal privacy were

This article is an open access article distributed under the terms and conditions of the Creative Commons Attribuion (CC BY-SA) license (http://creativecommons.org/licenses/by/4.0/) 
respected at all levels of the study. Collected data were not used for any other purpose. The study has been carried out in accordance with the Code of Ethics of the World Medical Association (Declaration of Helsinki) for studies involving humans.

Inclusion criteria: Patients age 18 years and older of both genders presented with ST-elevation myocardial infarction or new left bundle branch block (LBBB).

Exclusion criteria: Prior myocardial infarction. Prior systolic dysfunction (ejection fraction $<40 \%$ ). Prior coronary artery bypass graft. Previously stent implantation. Severe vessel tortuosity. Diffuse disease or severe calcification. Patients with preexisting valvular heart disease (HD). Patients with chronic arrhythmias. Advanced hepatic and renal diseases.

Patients fulfilling inclusion criteria were recruited to the study from the attendants of Zagazig University Hospitals and were randomized into three groups: (1) Manual aspiration group (16 patients). (2) Manual aspiration with intracoronary glycoprotein IIb/IIIa group (19 patients), and (3) Intracoronary glycoprotein IIb/IIIa group (13 patients).

All patients involved in the study were subjected to: Patient History and examination included: Age. Sex. Risk factors for coronary artery disease: (Smoking, hypertension, diabetes mellitus, hyperlipidemia). Family history of chronic heart disease. Obesity. History of chronic kidney disease (CKD) detected by high serum creatinine. Lower extremities arterial disease. Prior myocardial infarction or coronary artery bypass graft. Patients' vital data including arterial blood pressure, heart rate, and 12 lead ECG on admission to detect presence and localization of ST-segment elevation myocardial infarction (STEMI) ${ }^{(12)}$.

Laboratory evaluation: Complete blood count. Renal function test. (Urea, creatinine). Serum electrolyte (NA, K, and $\mathrm{Cl}$ ). Coagulation profile (PT, PTT, and INR). A cardiac enzyme (CKMB and troponin). Serology test (HBV, HCV, and HIV).
Other investigations: Electrocardiography (ECG) included; ST-segment elevation. New left bundle branch block. Right-sided leads electrocardiography. Posterior sided leads electrocardiography, and echocardiography (Echo): evaluation of a systolic function at admission and after discharge.

All Patients were loaded with a dual antiplatelet regimen at the time of presentation (Aspirin $300 \mathrm{mg}$ and Ticagrelor $180 \mathrm{mg}$ ). Adequate anticoagulation was done using IV unfractionated heparin guided by anticoagulation time. All patients were diagnosed by angiography to determine the lesion (thrombus).

\section{Postoperative follow-up:}

Primary endpoint: Short-term follows up, in-hospital outcomes regarding death, heart failure, reinfarction, and stroke. Infarct size as reflected by segmental wall motion score assessment.

Secondary endpoint: Major Adverse Cardiac and Cerebrovascular Events (MACCE) included: Heart failure, stroke, reinfarction, and death. Left ventricular systolic function. Bleeding. Thrombocytopenia.

\section{Statistical analysis}

The collected data were coded, processed and analyzed using the SPSS (Statistical Package for the Social Sciences) version 22 for Windows ${ }^{\circledR}$ (IBM SPSS Inc, Chicago, IL, USA). Data were tested for normal distribution using the Shapiro Wilk test. Qualitative data were represented as frequencies and relative percentages. Chi square test $\left(\chi^{2}\right)$ was used to calculate difference between two or more groups of qualitative variables. Quantitative data were expressed as mean \pm SD (Standard deviation), and range. Paired t-test was used to compare between two paired means of the same group. $\mathrm{P}$ value $<0.05$ was considered significant and $\mathrm{P}<0.001$ was considered highly significant.

\section{RESULTS}

The age of the studied participants ranged between 25 and 73 years with mean age of 56 years. More than half of them were males (Table 1).

Table (1): Baseline characteristics of the studied group

\begin{tabular}{|c|c|c|}
\hline \multirow[t]{2}{*}{ Variable } & \multicolumn{2}{|c|}{$\begin{array}{c}\text { Studied group } \\
(n=48)\end{array}$} \\
\hline & No & $\%$ \\
\hline $\begin{array}{l}\text { Sex: } \\
\text { Female: } \\
\text { Male: }\end{array}$ & $\begin{array}{l}19 \\
29\end{array}$ & $\begin{array}{l}39.6 \\
60.4\end{array}$ \\
\hline $\begin{array}{l}\text { Age: } \\
\text { Mean } \pm \text { SD } \\
\text { Range }\end{array}$ & \multicolumn{2}{|c|}{$\begin{array}{c}56.3 \pm 11.3 \\
25-73\end{array}$} \\
\hline
\end{tabular}

Table 2 shows that there was non-significant difference between the studied groups regarding all medical and clinical histories. 
Table (2): Relationship of medical and clinical histories among the studied groups

\begin{tabular}{|c|c|c|c|c|}
\hline \multirow{2}{*}{ Variable } & $\begin{array}{l}\text { Manual aspiration } \\
\text { group }(n=16)\end{array}$ & $\begin{array}{l}\text { Manual aspiration + IC GP } \\
\text { IIb/IIIa group }(n=19)\end{array}$ & $\begin{array}{l}\text { IC GP IIb/IIIa } \\
\operatorname{group}(n=13)\end{array}$ & \multirow[t]{2}{*}{ P-value } \\
\hline & $\mathbf{N}(\%)$ & $\mathrm{N}(\%)$ & $\mathrm{N}(\%)$ & \\
\hline $\begin{array}{r}\text { Smoking: } \\
\text { No: } \\
\text { Yes: }\end{array}$ & $\begin{array}{c}5(31.3) \\
11(68.7)\end{array}$ & $\begin{array}{l}10(52.6) \\
9(47.4)\end{array}$ & $\begin{array}{l}5(38.5) \\
8(61.5)\end{array}$ & 0.425 \\
\hline $\begin{array}{c}\text { Diabetes mellitus: } \\
\text { No: } \\
\text { Yes: }\end{array}$ & $\begin{array}{l}7(43.8) \\
9(56.3)\end{array}$ & $\begin{array}{l}10(52.6) \\
9(47.4)\end{array}$ & $\begin{array}{l}4(30.8) \\
9(69.2)\end{array}$ & 0.473 \\
\hline $\begin{array}{c}\text { Hypertension: } \\
\text { No: } \\
\text { Yes: }\end{array}$ & $\begin{array}{l}4(25) \\
12(75)\end{array}$ & $\begin{array}{l}4(21.1) \\
15(78.9)\end{array}$ & $\begin{array}{l}3(23.1) \\
10(76.9)\end{array}$ & 0.962 \\
\hline $\begin{array}{c}\text { Dyslipidemia: } \\
\text { No: } \\
\text { Yes: }\end{array}$ & $\begin{array}{l}8(50) \\
8(50)\end{array}$ & $\begin{array}{l}8(42.1) \\
11(57.9)\end{array}$ & $\begin{array}{l}5(38.5) \\
8(61.5)\end{array}$ & 0.810 \\
\hline $\begin{array}{c}\text { Coronary artery } \\
\text { disease: } \\
\text { No: } \\
\text { Yes: } \\
\end{array}$ & $\begin{array}{c}15(93.8) \\
1(6.3) \\
\end{array}$ & $\begin{array}{c}13(68.4) \\
6(31.6) \\
\end{array}$ & $\begin{array}{l}11(84.6) \\
2(15.4) \\
\end{array}$ & 0.150 \\
\hline $\begin{array}{l}\text { Obesity: } \\
\text { No: } \\
\text { Yes: }\end{array}$ & $\begin{array}{l}11(68.8) \\
5(31.2)\end{array}$ & $\begin{array}{l}8(42.1) \\
11(57.9)\end{array}$ & $\begin{array}{l}6(46.2) \\
7(53.8)\end{array}$ & 0.256 \\
\hline $\begin{array}{c}\text { Chronic kidney } \\
\text { disease: } \\
\text { No: } \\
\text { Yes: } \\
\end{array}$ & $\begin{array}{c}16(100) \\
0(0) \\
\end{array}$ & $\begin{array}{c}19(100) \\
0(0) \\
\end{array}$ & $\begin{array}{c}13(100) \\
0(0) \\
\end{array}$ & 1 \\
\hline $\begin{array}{ll}\text { LEAD: } & \\
& \text { No: } \\
& \text { Yes: } \\
\end{array}$ & $\begin{array}{c}16(100) \\
0(0) \\
\end{array}$ & $\begin{array}{c}19(100) \\
0(0) \\
\end{array}$ & $\begin{array}{c}13(100) \\
0(0) \\
\end{array}$ & 1 \\
\hline $\begin{array}{l}\text { Acute MI: } \\
\text { Antero-inferior } \\
\text { STEMI: } \\
\text { Anterior STEMI: } \\
\text { Inferior STEMI: }\end{array}$ & $\begin{array}{c}2(12.5) \\
6(37.5) \\
8(50)\end{array}$ & $\begin{array}{c}4(21.1) \\
10(52.6) \\
5(26.3)\end{array}$ & $\begin{array}{l}1(7.7) \\
6(46.2) \\
6(46.2)\end{array}$ & 0.579 \\
\hline $\begin{array}{r}\text { New LBBB: } \\
\text { No: } \\
\text { Yes: } \\
\end{array}$ & $\begin{array}{l}14(87.5) \\
2(12.5)\end{array}$ & $\begin{array}{l}17(89.5) \\
2(10.5)\end{array}$ & $\begin{array}{c}13(100) \\
0(0)\end{array}$ & 0.435 \\
\hline $\begin{array}{c}\text { Thrombus grade: } \\
\text { Grade III: } \\
\text { Grade V: }\end{array}$ & $\begin{array}{l}4(25) \\
12(75)\end{array}$ & $\begin{array}{l}11(57.9) \\
8(42.1)\end{array}$ & $\begin{array}{l}7(53.8) \\
6(46.2)\end{array}$ & 0.115 \\
\hline
\end{tabular}

Table 3 shows that there was non-significant difference between the studied groups regarding cardiac enzymes (troponin and CK-MB).

Table (3): Cardiac enzymes among the studied groups

\begin{tabular}{|c|c|c|c|c|}
\hline Variable & $\begin{array}{c}\text { Manual aspiration } \\
\text { group }(\mathbf{n = 1 6})\end{array}$ & $\begin{array}{c}\text { Manual aspiration }+ \\
\text { IC GP IIb/IIIa group } \\
(\mathbf{n}=\mathbf{1 9})\end{array}$ & $\begin{array}{c}\text { IC } \\
\text { GP IIb/IIIa group } \\
(\mathbf{n = 1 3})\end{array}$ & P-value \\
\hline $\begin{array}{c}\text { Troponin (ng/ml) } \\
\text { Mean } \pm \text { SD }\end{array}$ & $944 \pm 80$ & $1343 \pm 48$ & $1168 \pm 40$ & 0.290 \\
\hline $\begin{array}{c}\text { CK-MB } \\
\text { Mean } \pm \text { SD }\end{array}$ & $41.3 \pm 7.4$ & $42.7 \pm 7.2$ & $39.6 \pm 6.6$ & 0.508 \\
\hline
\end{tabular}


Table 4 shows that there was non-significant difference between the studied groups regarding kidney function tests except creatinine (renal insufficiency) which was found to be significantly higher among patients underwent manual aspiration compared to others.

Table (4): Kidney function tests and serum electrolytes among the studied groups

\begin{tabular}{|c|c|c|c|c|}
\hline Variable & $\begin{array}{c}\text { Manual aspiration } \\
\text { group } \\
(\mathbf{n = 1 6})\end{array}$ & $\begin{array}{c}\text { Manual aspiration }+ \\
\text { IC GP IIb/IIIa group } \\
(\mathbf{n = 1 9 )}\end{array}$ & $\begin{array}{c}\text { IC } \\
\text { GP IIb/IIIa group } \\
(\mathbf{n = 1 3})\end{array}$ & P-value \\
\hline $\begin{array}{c}\text { Urea }(\mathbf{m g} / \mathbf{d L}) \\
\text { Mean } \pm \text { SD }\end{array}$ & $19.9 \pm 4.3$ & $17.3 \pm 3.5$ & $18.8 \pm 2.5$ & 0.246 \\
\hline $\begin{array}{c}\text { Creatinine } \\
(\boldsymbol{\mu m o l} / \mathbf{L}) \\
\text { Mean } \pm \text { SD }\end{array}$ & $1.1 \pm 0.2$ & $0.94 \pm 0.1$ & $0.98 \pm 0.2$ & $\mathbf{0 . 0 1}$ \\
\hline $\begin{array}{c}\text { Sodium (mEq/L) } \\
\text { Mean } \pm \text { SD }\end{array}$ & $139.8 \pm 4.0$ & $138.6 \pm 4.1$ & $141.2 \pm 3.6$ & 0.185 \\
\hline $\begin{array}{l}\text { Potassium } \\
(\mathbf{m E q} / \mathbf{L}) \\
\text { Mean } \pm \text { SD }\end{array}$ & $4.9 \pm 0.5$ & $4.9 \pm 0.4$ & $5.1 \pm 0.1$ & 0.618 \\
\hline
\end{tabular}

Table 5 shows that there was non-significant difference between the studied groups regarding CBC and coagulation profile. However, INR and PTT were significantly higher among patients underwent manual aspiration + IC GP IIb/IIIa compared to those underwent manual aspiration technique alone and those underwent IC GP IIb/IIIa.

Table (5): CBC and coagulation profile among the studied groups

\begin{tabular}{|l|c|c|c|c|}
\hline Variable & $\begin{array}{c}\text { Manual aspiration } \\
\text { group } \\
(\mathbf{n = 1 6})\end{array}$ & $\begin{array}{c}\text { Manual aspiration }+ \\
\text { IC GP Ilb/IIIa group } \\
(\mathbf{n = 1 9 )}\end{array}$ & $\begin{array}{c}\text { IC } \\
\text { GP IIb/IIIa group } \\
(\mathbf{n = 1 3})\end{array}$ & P-value \\
\hline $\begin{array}{c}\text { WBCs }(\mathbf{m c L}) \\
\text { Mean } \pm \text { SD }\end{array}$ & $10.5 \pm 3$ & $10.1 \pm 2.3$ & $10.7 \pm 2.4$ & 0.816 \\
\hline $\begin{array}{c}\text { Hemoglobin (g/dL) } \\
\text { Mean } \pm \text { SD }\end{array}$ & $13.7 \pm 0.9$ & $12.9 \pm 1.3$ & $13.3 \pm 1.5$ & 0.206 \\
\hline $\begin{array}{c}\text { Platelets (mcL) } \\
\text { Mean } \pm \text { SD }\end{array}$ & $257.7 \pm 17.5$ & $265.3 \pm 52.9$ & $309.2 \pm 57.5$ & 0.081 \\
\hline $\begin{array}{l}\text { INR: } \text { Mean } \pm \text { SD } \\
\text { PTT: }\end{array}$ Mean \pm SD & $1.04 \pm 0.09$ & $1.1 \pm 0.1$ & $1.04 \pm 0.1$ & $\mathbf{0 . 0 4}$ \\
\hline PT: $\quad 35.7 \pm 4.1$ & $37.3 \pm 4.4$ & $30.4 \pm 4.7$ & $\mathbf{0 . 0 3}$ \\
\hline Mean \pm SD & $11.9 \pm 1.1$ & $12.4 \pm 1.1$ & $12.2 \pm 1.4$ & 0.379 \\
\hline
\end{tabular}

Table 6 shows that there was non-significant difference between the studied groups regarding echo (Ejection fraction \%) findings at admission. However, echo (Ejection fraction \%) findings were significantly higher among patients underwent manual aspiration + IC GP IIb/IIIa compared to those underwent manual aspiration technique alone and those underwent IC GP IIb/IIIa. By comparing the percent increase in echo (Ejection fraction \%) findings among the studied groups, the increase was the highest among those who underwent manual aspiration + IC GP IIb/IIIa.

Table (6): Echo (ejection fraction \%) at different timings among the studied groups

\begin{tabular}{|l|c|c|c|c|}
\hline Variable & $\begin{array}{c}\text { Manual aspiration } \\
\text { group } \\
(\mathbf{n = 1 6})\end{array}$ & $\begin{array}{c}\text { Manual aspiration }+ \\
\text { IC GP IIb/IIIa group } \\
(\mathbf{n = 1 9 )}\end{array}$ & $\begin{array}{c}\text { IC } \\
\text { GP IIb/IIIa group } \\
(\mathbf{n = 1 3})\end{array}$ & P-value \\
\hline $\begin{array}{c}\text { At admission: } \\
\text { Mean } \pm \text { SD }\end{array}$ & $52.3 \pm 6.1$ & $53.2 \pm 4.9$ & $51.2 \pm 7.6$ & 0.257 \\
\hline At discharge: Mean \pm SD & $49 \pm 8.5$ & $55.5 \pm 4.1$ & $47.3 \pm 9.8$ & $\mathbf{0 . 0 0 8}$ \\
\hline P-value of paired means: & $\mathbf{0 . 0 0 3}$ & $<\mathbf{0 . 0 0 1}$ & $>0.05$ & \\
\hline \% Change: Mean \pm SD & $0.06 \pm 0.08$ & $-0.04 \pm 0.03$ & $0.07 \pm 0.1$ & $<\mathbf{0 . 0 0 1}$ \\
\hline
\end{tabular}


Table 7 shows that there was non-significant difference between the studied groups regarding occurrence of complications. However, there was significant difference between them in heart failure, bleeding and death occurrence which was found to be in the highest frequency among patients underwent IC GP IIb/IIIa compared to those underwent manual aspiration technique alone. No cases of heart failure, bleeding and death were recorded among patients underwent manual aspiration + IC GP IIb/IIIa.

Table (7): Complications among the studied groups

\begin{tabular}{|c|c|c|c|c|}
\hline \multirow[t]{2}{*}{ Variable } & $\begin{array}{c}\text { Manual aspiration } \\
\text { group } \\
(\mathbf{n}=16)\end{array}$ & $\begin{array}{l}\text { Manual aspiration + } \\
\text { IC GP IIb/IIIa group } \\
\qquad(n=19)\end{array}$ & $\begin{array}{c}\text { IC GP } \\
\text { IIb/IIIa } \\
\text { group } \\
(n=13) \\
\end{array}$ & \multirow[t]{2}{*}{ P-value } \\
\hline & $\mathbf{N}(\%)$ & $\mathbf{N}(\%)$ & $\mathbf{N}(\%)$ & \\
\hline $\begin{array}{r}\text { Heart failure: } \\
\text { No: } \\
\text { Yes: }\end{array}$ & $\begin{array}{c}13(81.3) \\
3(18.8) \\
\end{array}$ & $\begin{array}{c}19(100) \\
0(0) \\
\end{array}$ & $\begin{array}{l}8(61.5) \\
5(38.5) \\
\end{array}$ & 0.01 \\
\hline $\begin{array}{r}\text { Reinfarction: } \\
\text { No: } \\
\text { Yes: }\end{array}$ & $\begin{array}{c}16(100) \\
0(0)\end{array}$ & $\begin{array}{c}19(100) \\
0(0)\end{array}$ & $\begin{array}{c}13(100) \\
0(0)\end{array}$ & 1 \\
\hline $\begin{array}{l}\text { Bleeding: } \\
\text { No: } \\
\text { Yes: } \\
\end{array}$ & $\begin{array}{c}16(100) \\
0(0) \\
\end{array}$ & $\begin{array}{c}19(100) \\
0(0) \\
\end{array}$ & $\begin{array}{c}11(84.6) \\
2(15.4) \\
\end{array}$ & 0.062 \\
\hline $\begin{array}{c}\text { Thrombocytopenia: } \\
\text { No: } \\
\text { Yes: } \\
\end{array}$ & $\begin{array}{c}16(100) \\
0(0) \\
\end{array}$ & $\begin{array}{c}19(100) \\
0(0) \\
\end{array}$ & $\begin{array}{c}13(100) \\
0(0) \\
\end{array}$ & 1 \\
\hline $\begin{array}{l}\text { Stroke: } \\
\\
\\
\text { No: } \\
\text { Yes: }\end{array}$ & $\begin{array}{c}16(100) \\
0(0)\end{array}$ & $\begin{array}{c}19(100) \\
0(0)\end{array}$ & $\begin{array}{c}13(100) \\
0(0)\end{array}$ & 1 \\
\hline $\begin{array}{ll}\text { Death: } & \\
& \text { Alive: } \\
& \text { Dead: } \\
\end{array}$ & $\begin{array}{c}16(100) \\
0(0)\end{array}$ & $\begin{array}{c}19(100) \\
0(0) \\
\end{array}$ & $\begin{array}{c}11(84.6) \\
2(15.4) \\
\end{array}$ & 0.062 \\
\hline $\begin{array}{c}\text { Serology: } \\
\text { Negative: } \\
\text { Positive: }\end{array}$ & $\begin{array}{c}16(100) \\
0(0)\end{array}$ & $\begin{array}{c}19(100) \\
0(0)\end{array}$ & $\begin{array}{c}13(100) \\
0(0) \\
\end{array}$ & 1 \\
\hline
\end{tabular}

Table 8 shows that there was non-significant difference between the studied groups regarding the perfusion score at baseline and after PCI. There was significant difference among manual aspiration + IC GP IIb/III a group as regarding perfusion score at baseline and after PCI.

Table (8): Relationship of baseline characteristics among the studied groups

\begin{tabular}{|c|c|c|c|c|}
\hline Variable & $\begin{array}{c}\text { Manual aspiration } \\
\text { group } \\
(\mathrm{n}=16)\end{array}$ & $\begin{array}{c}\text { Manual aspiration } \\
+ \\
\text { IC GP IIb/IIIa } \\
\text { group } \\
(\mathbf{n}=19) \\
\end{array}$ & $\begin{array}{c}\text { IC } \\
\text { GP IIb/IIIa } \\
\text { group } \\
(\mathbf{n}=13) \\
\end{array}$ & P-value \\
\hline & $\mathbf{N}(\%)$ & $\mathbf{N}(\%)$ & $\mathbf{N}(\%)$ & \\
\hline $\begin{array}{l}\text { Perfusion score at } \\
\text { baseline: } \\
\text { Timi-3 flow } \\
\text { No flow }\end{array}$ & $\begin{array}{c}10(62.5) \\
6(37.5)\end{array}$ & $\begin{array}{c}11(57.9) \\
8(42.1)\end{array}$ & $\begin{array}{l}9(69.2) \\
4(30.8)\end{array}$ & 0.809 \\
\hline $\begin{array}{l}\text { Perfusion score aft } \\
\text { PCI: } \\
\text { Timi-3 flow } \\
\text { No flow }\end{array}$ & $\begin{array}{c}11(68.8) \\
5(31.2)\end{array}$ & $\begin{array}{c}18(94.7) \\
1(5.3)\end{array}$ & $\begin{array}{c}11(84.6) \\
2(15.4)\end{array}$ & 0.119 \\
\hline P-VALUE: & 0.709 & 0.007 & 0.351 & \\
\hline
\end{tabular}




\section{DISCUSSION}

The current study showed that there was nonsignificant difference between the studied groups as regarding bleeding. This agrees with the results of Niu et al. ${ }^{(13)}$ who aimed to evaluate the role of aspiration thrombectomy (AT) combined with intracoronary administration of glycoprotein IIb/IIIa inhibitors (GPI) in the improvement of myocardial reperfusion and clinical outcomes. They found that there was no significant difference between the two groups in the incidence of minor and major bleeding complications, suggesting comparable safety. According to Wu et al. (14) who aimed to assess the effects of intracoronary GPIs after thrombus aspiration compared with PCI alone in STEMI patients from the year 2008 to 2015. They found that there was no significant difference between the number of bleeding events in the intracoronary GPIs group and those in the control group, despite GPIs' antiplatelet activity and the risk of bleeding. This might be due to the type of GPIstirofiban, which was mostly used in our meta-analysis (92.9\% used tirofiban). Kelly et al. ${ }^{(\mathbf{1 5})}$ also reported that only 1 case of major bleeding (2.9\%) among 34 patients after intracoronary thrombolysis using tenecteplase, which is similar to the major bleeding rates reported regularly in acute coronary syndrome (16). Moreover, the majority of the patients $(76 \%)$ in their study received glycoprotein IIb/IIIa inhibitors simultaneously with intracoronary thrombolysis.

There was non-significant difference between the studied groups regarding Death. Two cases were died in IC GP IIb/IIIa group. A previous meta-analysis pooling the individual data of 2686 patients enrolled in 11 RCTs indicated that the combination of AT and abciximab was associated with a significantly reduced rate of mortality at a median follow-up of one year compared to AT alone (hazard ratio (HR): $0.61,95 \%$

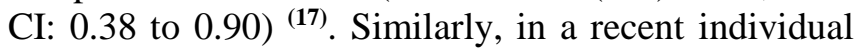
patient meta-analysis of more than 18000 patients with STEMI, patients treated with both AT and GPI had a lower risk of cardiovascular death within 30 days compared to those receiving AT only (HR: 0.63, 95\% CI: 0.44 to 0.88$)^{(18)}$. These two meta-analyses suggested that concomitant administration of intravenous GPI could enhance the clinical benefits observed with $\mathrm{AT}^{(\mathbf{1 7})}$.

TAPAS (Thrombus aspiration during percutaneous coronary intervention in acute myocardial infarction study) trial involving 1071 patients with STEMI, showed decrease in MACE (death) with thrombus aspiration as compared to primary PCI alone. In contrast, two large studies, TASTE (Thrombus aspiration during ST-segment elevation myocardial infarction) and TOTAL (ThrOmbecTomy with PCI versus PCI Alone) have not shown benefit of routine thrombus aspiration ${ }^{(\mathbf{1 9})}$.

In the randomized TASTE trial, including 7244 patients, no overall clinical effect was documented after
30 days or after 1 year: at 30 days, all-cause mortality rate was $2.8 \%$ (103 of 3621 patients) in the thrombus aspiration (TA) and 3.0\% (110 of 3623 patients) in the PCI-only group; rate of rehospitalization because of reinfarction was $0.5 \%$ in the TA group (19 of 3399 patients) and $0.9 \%$ in the PCI-only group; rates of stent thrombosis and TVR also did not differ between the 2 groups. The rates of stroke or neurological complications, perforation or tamponade, heart failure or LV dysfunction at the time of discharge/during hospital stay were also similar between the 2 groups ${ }^{(20)}$. Similarly, all-cause mortality rates after 1 year were $5.3 \%$ in the TA group (191 of 3621 patients) and 5.6\% (202 of 3623 patients) in the PCI-only group, rates of rehospitalization for MI were $2.7 \%$ versus $2.7 \%$, and the rates of stent thrombosis $0.7 \%$ versus $0.9 \%$, therefore, overall results were comparable between the 2 groups ${ }^{(21)}$.

Mortality rates in Noman et al. ${ }^{(22)}$ study were significantly lower in this group compared with those with post-PPCI TIMI 0/1/2 flow. These findings of improved post-PPCI TIMI 3 flow with thrombectomy give some insights into the potential mechanism by which thrombectomy may impact on the survival of STEMI patients.

In our study, two cases in IC GP IIb/IIIa group had bleeding. In a meta-analysis of 10,123 patients undergoing primary PCI, nonfatal MI at 30 days was reduced from 8.3 to $5.1 \%(\mathrm{p}<0.001)$ with use of GPIIb/IIIa inhibitors at the expense of a significant increase in the risk of minor bleeding ( 3 vs. $1.7 \%$; $p$ < $0.001)$ and thrombocytopenia (0.8 vs. $0.04 \% ; \mathrm{p}=$ $0.004)^{(23)}$. Shimada et al. ${ }^{(24)}$ demonstrated a favorable effect of intracoronary bolus of GPI during PCI with no increase in bleeding risk.

There was non-significant difference between the studied groups regarding stroke. In contrast, the beneficial effects of TA have been challenged by the results of two major randomized multicenter trials, TASTE and TOTAL, which demonstrated that routine TA increased the risk of stroke ${ }^{(21,25)}$. In a metaanalysis, thrombus aspiration was associated with a trend toward an increased rate of stroke $(\mathrm{P}=0.06){ }^{(26)}$. However, in the TASTE trial, there was no significant difference between the groups in the rates of stroke and neurologic complications.

The present study showed that there was nonsignificant difference between the studied groups regarding reinfarction. The main findings of Wu et al. ${ }^{(14)}$ meta-analysis are the incidence of short-term MACE was significantly reduced with intracoronary GPIs after thrombus aspiration, including death and reinfarction.

In a retrospective study exploring the role of AT combined with intracoronary administration of GPI in patients with STEMI, Yan $\boldsymbol{e t}$ al. ${ }^{(27)}$ reported that the combination treatment was related with improved myocardial perfusion, saved more myocardium, and resulted in better clinical prognoses. 
Eleven cases had Timi-3 flow and 2 had no flow in IC GP IIb/IIIa group. Shimada et al. (24) demonstrated a favourable effect of intracoronary bolus of GPI during PCI on TIMI flow.

Eleven cases had Timi-3 flow and 5 had no flow in manual aspiration group. Gao et al. ${ }^{(28)}$ found that patients in the TA group had better Thrombolysis in Myocardial Infarction (TIMI) flow grade classifications and lower incidence of no/slow reflow and MACE compared with conventional PCI alone. Additionally, the MACE rate was also lower in the TA group during the 6-month follow-up. A potential mechanism might be reduced platelet activation, which was suggested by Sahin et al. ${ }^{(29)}$ when using TA in patients with STEMI during PPCI. Accordingly, Härle et al. ${ }^{(30)}$ reported a heterogeneous use of TA in patients with STEMI between interventionalists and hospitals. Although there was no impact of TA on TIMI 3 patency or mortality after PPCI, a positive impact when using individualized TA on restoration of normal blood flow in the subgroup of STEMI patients with TIMI 0 flow before PPCI was described. The main findings of Bin et al. ${ }^{(31)}$ retrospective cohort study were that compared with conventional PPCI, PPCI with TA significantly improved the outcome in patients with STEMI and a large thrombus burden, such as a higher rate of postprocedural TIMI 3 flow. Recent prospective randomization clinical trials confirmed that TA improved myocardial perfusion ${ }^{(32)}$.

De Luca et $\boldsymbol{a l}{ }^{(5)}$ analyzed nine randomized trials with 2, 417 patients and compared PCI using manual thrombectomy with PCI alone. This meta-analysis found that manual thrombectomy was associated with more frequent TIMI 3 flow post-PCI (87\% versus $81 \%$, p< 0.0001 ), more frequent grade 3 myocardial blush (MBG 3) (52\% versus $32 \%, \mathrm{p}<0.0001)$, less distal emboli ( $7.9 \%$ versus $19.5 \%, \mathrm{p}<0.0001)$ and lower 30-day mortality ( $1.7 \%$ versus $3.1 \%, \mathrm{p}=0.04$ ) compared to $\mathrm{PCI}$ alone.

Eighteen cases had Timi-3 flow and 1 had no flow in manual aspiration + IC GP IIb/IIIla group. Wu et al. (14) found that intracoronary GPIs after thrombus aspiration provided significant benefits in postprocedural TIMI flow grade 3, complete STR when compared with PCI alone.

\section{CONCLUSION}

There was significant difference between manual aspiration group, manual aspiration with intracoronary glycoprotein IIb/IIIa group and intracoronary glycoprotein IIb/IIIa group as regard the outcomes in high thrombus burden patients. GPIs may have a synergistic effect with thrombus aspiration, while alone has a negative effect.

\section{Financial support and sponsorship: Nil.}

Conflict of interest: Nil.

\section{REFERENCES}

1. Stone G, Selker H, Thiele H et al. (2016): Relationship between infarct size and outcomes following primary PCI: patient-level analysis from 10 randomized trials. Journal of the American College of Cardiology, 67(14): 1674-83.

2. Huynh T, Perron S, O'Loughlin J et al. (2009): Comparison of primary percutaneous coronary intervention and fibrinolytic therapy in randomized controlled studies and observational studies: Results of hierarchical Bayesian meta-analyses. Circulation, 119(24): 3101-9.

3. Wu E, Ortiz J, Tejedor P et al. (2008): Infarct size by contrast enhanced cardiac magnetic resonance is a stronger predictor of outcomes than left ventricular ejection fraction or end-systolic volume index: Prospective cohort study. Heart, 94(6): 730-6.

4. Thiele H, Schindler K, Friedenberger J et al. (2008): Intracoronary compared with intravenous bolus abciximab application in patients with ST-elevation myocardial infarction undergoing primary percutaneous coronary intervention: the randomized Leipzig immediate percutaneous coronary intervention abciximab IV versus IC in ST-elevation myocardial infarction trial. Circulation, 118(1): 49-57.

5. De Luca G, Dudek D, Sardella G et al. (2008): Adjunctive manual thrombectomy improves myocardial perfusion and mortality in patients undergoing primary percutaneous coronary intervention for ST-elevation myocardial infarction: a meta-analysis of randomized trials. European Heart Journal, 29(24): 3002-10.

6. Carrick D, Oldroyd K, McEntegart M et al. (2014): A randomized trial of deferred stenting versus immediate stenting to prevent no-or slow-reflow in acute ST-segment elevation myocardial infarction (DEFER-STEMI). Journal of the American College of Cardiology, 63(20): 2088-98.

7. Mayr A, Mair J, Klug G et al. (2011): Cardiac troponin $\mathrm{T}$ and creatine kinase predict mid-term infarct size and left ventricular function after acute myocardial infarction: a cardiac MR study. Journal of Magnetic Resonance Imaging, 33(4): 847-54.

8. De Luca G, Verdoia M, Suryapranata H (2012): Benefits from intracoronary as compared to intravenous abciximab administration for STEMI patients undergoing primary angioplasty: a meta-analysis of 8 randomized trials. Atherosclerosis, 222(2): 426-33.

9. Thiele H, Wöhrle J, Hambrecht $\mathrm{R}$ et al. (2012): Intracoronary versus intravenous bolus abciximab during primary percutaneous coronary intervention in patients with acute ST-elevation myocardial infarction: a randomised trial. The Lancet, 379(9819): 923-31.

10. Piccolo R, Eitel I, Iversen A et al. (2014): Intracoronary versus intravenous bolus abciximab administration in patients undergoing primary percutaneous coronary intervention with acute STelevation myocardial infarction: a pooled analysis of individual patient data from five randomised controlled trials. Euro Intervention, 9(9): 1110-20.

11. Steg P, Mehta S, Pollack C et al. (2012): Design and rationale of the treatment of acute coronary syndromes with otamixaban trial: A double-blind triple-dummy 2stage randomized trial comparing otamixaban to unfractionated heparin and eptifibatide in non-STsegment elevation acute coronary syndromes with a planned early invasive strategy. American Heart Journal, 164(6): 817-24. 
12. Sorajja $P$, Gersh B, Costantini C et al. (2005): Combined prognostic utility of ST-segment recovery and myocardial blush after primary percutaneous coronary intervention in acute myocardial infarction. European Heart Journal, 26(7): 667-74.

13. Niu X, Zhang J, Bai $M$ et al. (2017): Combined thrombectomy and intracoronary administration of glycoprotein IIb/IIIa inhibitors improves myocardial reperfusion in patients undergoing primary percutaneous coronary intervention: a meta-analysis. J Geriatr Cardiol., 14(10): 614-623.

14. Wu J, Hao P, Chen Y et al. (2018): Intracoronary glycoprotein IIb/IIIa inhibitors improve short-term mortality and reinfarction in East Asian patients with ST-segment elevation myocardial infarction after thrombus aspiration: A Meta-Analysis. Evid Based Complement Alternat Med., 18: 714-18.

15. Kelly R, Crouch E, Krumnacher H et al. (2005): Safety of adjunctive intracoronary thrombolytic therapy during complex percutaneous coronary intervention: initial experience with intracoronary tenecteplase. Catheter Cardiovasc Interv., 66(3): 327-32.

16. Moscucci M, Fox K, Cannon C et al. (2003): Predictors of major bleeding in acute coronary syndromes: the global registry of acute coronary events (GRACE). Eur Heart J., 24(20): 1815-23.

17. Burzotta F, De Vita M, Gu Y et al. (2009): Clinical impact of thrombectomy in acute ST-elevation myocardial infarction: an individual patient-data pooled analysis of 11 trials. European Heart Journal, 30(18): 2193-203.

18. Jolly S, James S, Džavík V et al. (2017): Thrombus aspiration in ST-segment-elevation myocardial infarction: an individual patient meta-analysis: Thrombectomy Trialists Collaboration. Circulation, 135(2): 143-52.

19. Vlaar P, Svilaas T, van der Horst I et al. (2008): Cardiac death and reinfarction after 1 year in the Thrombus Aspiration during Percutaneous coronary intervention in Acute myocardial infarction Study (TAPAS): a 1-year follow-up study. The Lancet, 371(9628): 1915-20.

20. Fröbert O, Lagerqvist B, Olivecrona G et al. (2013): TASTE Trial. Thrombus aspiration during ST-segment elevation myocardial infarction. N Engl J Med., 369: 1587-1597.

21. Lagerqvist B, Fröbert O, Olivecrona G et al. (2014): Outcomes 1 year after thrombus aspiration for myocardial infarction. New England Journal of Medicine, 371(12): 1111-20.

22. Noman A, Egred M, Bagnall A et al. (2012): Impact of thrombus aspiration during primary percutaneous coronary intervention on mortality in ST-segment elevation myocardial infarction. European Heart Journal, 33(24): 3054-61.

23. Winchester D, Wen X, Brearley W (2011): Efficacy and safety of glycoprotein IIb/IIIa inhibitors during elective coronary revascularization: a meta-analysis of randomized trials performed in the era of stents and thienopyridines. J Am Coll Cardiol., 57: 1190-1199.

24. Shimada Y, Nakra N, Fox J et al. (2012): Metaanalysis of prospective randomized controlled trials comparing intracoronary versus intravenous abciximab in patients with ST-elevation myocardial infarction undergoing primary percutaneous coronary intervention. The American Journal of Cardiology, 109(5): 624-8.

25. Jolly S, Cairns J, Yusuf S et al. (2015): Randomized trial of primary PCI with or without routine manual thrombectomy. N Engl J Med., 372(15): 1389-98.

26. De Luca G, Navarese E, Suryapranata H (2013): A meta-analytic overview of thrombectomy during primary angioplasty. Int J Cardiol., 166: 606-612.

27. Yan H, Li S, Li S et al. (2010): Thrombus aspiration plus intra-infarct-related artery administration of tirofiban improves myocardial perfusion during primary angioplasty for acute myocardial infarction. Chinese Medical Journal, 123(7): 877-83.

28. Gao L, Cao Z, Zhang H (2016): Efficacy and safety of thrombectomy combined with intracoronary administration of tirofiban in ST-segment elevation myocardial infarction (STEMI). Med Sci Monit., 22: 2699-2705.

29. Sahin M, Acar G, Kalkan M et al. (2015): Thrombus aspiration during primary percutaneous coronary intervention associated with reduced platelet activation. Saudi Med J., 36: 935-939.

30. Härle T, Zeymer U, Hochadel M et al. (2015): Use and impact of thrombectomy in primary percutaneous coronary intervention for acute myocardial infarction with persistent ST-segment elevation: results of the prospective ALKK PCI-registry. Clin Res Cardiol., 104: 803-811.

31. Bin N, Zhang F, Song $X$ et al. (2021): Thrombus aspiration during primary percutaneous coronary intervention improved outcome in patients with STEMI and a large thrombus burden. Journal of International Medical Research, 49(5): 352-360.

32. Li P, Ruan J, Liu M et al. (2019): Thrombus aspiration catheter improve the myocardial reperfusion of STEMI patients with high thrombus load during the emergency PCI operation. Journal of Cardiothoracic Surgery, 14(1): 1-6. 